\title{
Heavy Metal Concentrations in a Soil Irrigated with Treated Municipal Wastewater: Use of Mixed Effects Models to Analyse the Effect Over Time
}

\author{
Rita Leogrande ${ }^{1}$, Anna Maria Stellacci ${ }^{2 *}$, Pasquale Campi $^{1}$, Carolina Vitti ${ }^{1}$, Gaetano Alessandro Vivaldi ${ }^{3}$ and \\ Salvatore Camposeo ${ }^{3}$ \\ ${ }^{1}$ Council for Agricultural Research and Economics, Research Centre for Agriculture and Environment (CREA-AA), Italy \\ ${ }^{2}$ Department of Soil, Plant and Food Sciences (DiSSPA), University of Bari “Aldo Moro", Italy \\ ${ }^{3}$ Department of Agricultural and Environmental Science (DiSAAT), University of Bari "Aldo Moro", Italy \\ Submission: November 15, 2019; Published: December 10, 2019 \\ *Corresponding author: Anna Maria Stellacci, Department of Soil, Plant and Food Sciences (DiSSPA), University of Bari "Aldo Moro", via G. Amendola, \\ 165/A, 70126, Bari, Italy
}

Abstract

In arid and semi-arid regions of the world, non-conventional waters may represent an important complementary irrigation source. To investigate potential soil contaminations risks, repeated measurement experiments and rigorous methodological approaches may be adopted to assess variations of contaminant concentrations in the soil, eliminating possible confounding effects due to correlations over time. A field trial was carried out in Southern Italy to assess variation of heavy metals concentrations in a soil irrigated with:

(i) freshwater (FW),

(ii) a secondary-treated (SW),

(iii) a tertiary-treated municipal effluent (TW).

Concentrations of cadmium, chromium, copper, nickel, lead and zinc were quantified by ICP-OES on soil samples collected over three sampling dates. Mixed effects models accounting for residual autocorrelation were used to evaluate differences over time and treatments and the following variance-covariance structures were compared: compound symmetry (CS); autoregressive of first order (AR(1)); autoregressive of first order with heterogeneous variances (ARH(1)). ARH(1) models were significant in most of the cases investigated, confirming heterogeneity of variances observed over time. At the end of each irrigation season, soil heavy metal contents did not show significant differences among treatments. Significant interactions between water source and sampling time were observed mainly under SW and TW supply; in any case no increase of metals over time was recorded.

Our results confirmed low risk of soil metals contamination after short and medium term irrigation with treated municipal wastewater. However, when using non-conventional water resources, proper irrigation management and continuous monitoring of water and soil are needed to avoid soil degradation.

Keywords: Non-conventional water resources; Soil contaminants; Linear mixed effects models (LMM); Residual autocorrelation over time; Variance-covariance structures for residuals; Soil fertility

\section{Introduction}

Water scarcity and droughts are emerging as major issues worldwide, not only in dry lands, but also in areas where freshwater is abundant [1-4]. Due to increased agricultural production, irrigated land and consequently demand on water resources for irrigation have also increased, thus inducing competition for freshwater use with industries, municipalities and other sectors. These conditions, especially in arid and semiarid regions, such as Mediterranean environments, have forced farmers to use alternative water resources (i.e. brackish water, waste water, effluent water) for irrigating and narrowing the gap between freshwater availability and crop demand [5].

Irrigation with treated municipal wastewater plays a central role in environmental policies on a global scale and is receiving an increased attention of scientific community [6-8]. This practice represents a valid option, in some cases urged by the 
absence of viable alternatives $[9,10]$, not only to reduce the use and abstraction of freshwater, but also to avoid the discharge of effluents into water bodies $[1,11]$. In several countries treated wastewater is in fact already considered an appropriate water source for irrigation, mainly in agriculture and landscaping [12$14]$.

Despite the economic, social and environmental potential benefits deriving from the irrigation with treated municipal wastewater, reuse effects must be closely monitored to ensure the protection and the health of the resources, particularly soil. It is well known that irrigation with treated wastewater results in a significant amount of biodegradable organic material (carbon and nitrogen), mineral macro and meso-nutrients (such as phosphorous, potassium and magnesium) as well as micronutrients (e.g. molybdenum, selenium, boron and copper) necessary for crops growth. However, the risk of accumulation in the soil of pollutants in trace, heavy metals and salts, must not be ignored to preserve soil quality. Heavy metal concentrations in treated effluents are generally low because easily and efficiently removed during common treatment processes where the majority of these metals ends up in the biosolid fraction [11]. In any case, heavy metal contents in the effluents may vary with treatment process (less or more intensive) as well as with the source of wastewater (industrial, civil waste, etc.), thus concentrations in the receiving system (soil, plant) have to be monitored.

In addition, regardless of their content, such pollutants could accumulate in the soils, especially after continuous application in the long term, reaching concentrations harmful for crops [15-17] as well as for animals and human, when translocated and accumulated in the edible plant tissues. In particular, lead, cadmium, mercury, nickel, and arsenic are considered as "main threats" since adverse effects have been recorded at very low concentrations [18]. To this regard, Duran-Alvarez \& JimenesCisneros [19] have classified heavy metals as a function of risk factors on plants and human health (Table 1). Among soil properties, $\mathrm{pH}$, together with soil organic matter content, is the major factor affecting metal solubility, mobility and availability [20-22]. Heavy metals are in fact scarcely available at $\mathrm{pH}$ greater than 6.5 , since they precipitate, whereas at $\mathrm{pH}$ lower than 6.5 absorption sites tend to be saturated and metals enter progressively into the mobile phase; in these conditions they can be absorbed by crops or contaminate water bodies [23].

Table 1: Potential risks due to the presence of some metals in the soil. Adapted from Duran-Alvarez and Jimenes-Cisneros [15].

\begin{tabular}{|c|c|}
\hline Risks Characteristics & Metals \\
\hline Low risk & $\mathrm{Mn}, \mathrm{Fe}, \mathrm{Zn}, \mathrm{Cu}, \mathrm{Se}, \mathrm{Sb}$ \\
\hline High risk & $\mathrm{Cr}, \mathrm{As}, \mathrm{Pb}, \mathrm{Hg}, \mathrm{Ni}, \mathrm{Al}, \mathrm{Cd}$ \\
\hline Essential micronutrient to plants & $\mathrm{Cu}, \mathrm{Fe}, \mathrm{Mn}, \mathrm{Mo}, \mathrm{Zn}, \mathrm{Ni}$ \\
\hline Beneficial for some plants & $\mathrm{Co}, \mathrm{Na}, \mathrm{Si}$ \\
\hline Risk for accumulation in edible plant parts & $\mathrm{Cd}, \mathrm{Cu}, \mathrm{Mo}$ \\
\hline No human toxicological threshold established for wastewater irrigation & $\mathrm{Hg}$ \\
\hline Relatively high threshold for wastewater irrigation & $\mathrm{Cu}, \mathrm{Fe}, \mathrm{Mn}, \mathrm{Zn}$ \\
\hline Low absorption by plants & $\mathrm{Co}, \mathrm{Cu}, \mathrm{Mn}, \mathrm{Zn}$ \\
\hline
\end{tabular}

The prediction of the impact of irrigation with treated municipal wastewater on metal accumulation in soil is not easy due to the extreme complexity of the soil matrix and to the interactions with weather conditions, crop type and quantity and quality of water used for irrigation. For this reason, repeated measurements experiments over time, and comparison with conventional water supply, may provide useful information on possible impact and accumulation in the soil [10]. In addition, rigorous methodological approaches have to be adopted to correctly assess the effects of the factors investigated eliminating possible confounding effects due to correlation over time [23].

Failure to account for residual autocorrelation over time, in classical analysis of variance and standard linear models (OLS), may indeed cause inefficient estimation of treatment significance and increase the risk of misleading or erroneous inferences [2326].

The handling of complex models that allow to structure correlations decreasing with the distance in time or space has become feasible with the mixed model theory [27] for the availability of several variance-covariance models and for the facility to accommodate several error terms [28]. Although the adoption of these models is not straightforward, because requires the comparison of different variance-covariance structures for temporal components in order to choose the most explicative and parsimonious model, such approach should be included in the usual data analysis procedure, not only for long-term datasets.

In light of these considerations, the objective of this study was to assess the impact of irrigation with different municipal wastewaters on soil heavy metals accumulation. A two-years field research was performed under a typical Mediterranean environment in Southern Italy and repeated samplings were carried out in two contiguous experimental fields. For a deeper understanding of the effects of irrigation with different water sources on soil heavy metal concentrations, mixed effects models taking into account residual autocorrelation over time were applied to the data collected in the two experimental fields and compared to ordinary least squares models. 


\section{Materials and Methods}

\section{Site description and climate patterns}

The study was conducted over a two year period (2013-2014) in a Southern Italy area (Trinitapoli, lat. $41^{\circ} 21^{\prime} \mathrm{N}$, long. $16^{\circ} 03^{\prime}$ E, alt. $0 \mathrm{~m}$ a.s.l.) characterised by a Mediterranean climate, with average annual maximum and minimum air temperature of $19.3^{\circ} \mathrm{C}$ and $10.0^{\circ} \mathrm{C}$, respectively [8]. The average annual rainfall is $550 \mathrm{~mm}$ (30-year average), with precipitation occurring mostly during the autumn-winter period, while quite scarce during spring and summer. The average annual water deficit is $560 \mathrm{~mm}$, because the rainfall is insufficient to meet the evapotranspiration demand of the atmosphere [29].

The experimental area was divided in two parts and a contemporary-phase crop rotation (Field 1 and Field 2) of sorghum and sugar beet was adopted (Table 2). In detail, the trial started on January 2013 with sowing of sugar beet in field 1 and on May 2013 with sowing of sorghum in field 2. The fields were close to a municipal wastewater treatment plant.

Table 2: Contemporary crop rotation and sampling dates (in bracket the dates of crop sowing and harvesting are reported).

\begin{tabular}{|c|c|c|c|c|}
\hline \multirow{2}{*}{ Year } & \multicolumn{2}{|c|}{ Field 1 } & Crop & Field 2 \\
\cline { 2 - 5 } & Crop & Soil Sampling & Soil Sampling \\
\hline 2013 & Sugar beet (3rd January - 24th July) & September & Sorghum (21th May - 11th September) & May, September \\
\hline 2014 & Sorghum (28th May - 12th September) & May, September & Sugar beet (8th November 2013- 23th June 2014) & June \\
\hline
\end{tabular}

The soil was classified as clay-loam, with average contents in sand, silt and clay of $33 \%, 34 \%$ and $33 \%$, respectively (USDA classification); in $0-0.40 \mathrm{~m}$ soil layer, the contents in total organic carbon (TOC) and $\mathrm{N}$ were of $13.90 \mathrm{~g} \mathrm{~kg}^{-1}$ and $1.47 \mathrm{~g} \mathrm{~kg}^{-1}$ in field 1 and 10.39 and $0.79 \mathrm{~g} \mathrm{~kg}^{-1}$ in field 2; average $\mathrm{pH}$ was of 8.16 .

\section{Water sources and experimental design}

Three different water sources were compared in the experiment: a conventional water and two non-conventional water sources. The conventional water (freshwater, FW), served as control treatment, was supplied from water network of the Consorzio di Bonifica della Capitanata and coming straight from the Marana Capacciotti dam. The first non-conventional water was a secondary-treated municipal effluent (SW) originated from a public plant, using aerobic biological processes that consist of eliminating the biodegradable dissolved and colloidal organic matter; the clarified effluent is subsequently subjected to further treatments such as denitrification, dephosphorylation and disinfection. The second non-conventional water source was a tertiary-treated wastewater (TW) by the membrane filtration public plant. Specifically, the effluent from the secondary treatment was filtrated by an ultra-filtration module equipped with hollow fiber membranes (nominal porosity $0.2 \mu \mathrm{m}$ ) with cellulose triacetate double wall ( $0.8 \mathrm{~mm}$ diameter) at an internal pressure of $0.8-1.0$ bar, to break down the content of substances not removed during the previous treatments [30].

For all treatments, water was supplied by localized method, restoring $100 \%$ of the actual crop evapotranspiration (ETc), less the effective rainfall, occurred during each irrigation interval. ETc was calculated as follows: ETc $=$ Kc $\mathrm{x}$ ETo, where ETo was Hargreaves reference evapotranspiration and Kc was the crop coefficient. The seasonal irrigation volumes ranged from 3,000 to $3,500 \mathrm{~m} 3 \mathrm{ha}^{-1}$ and 1,100 to $1,500 \mathrm{~m} 3 \mathrm{ha}^{-1}$ for sorghum and sugar beet crop, respectively.
A randomized complete block design (RCBD) with three replications was adopted for each experimental field. Every block was divided then into three plots to study the effects of different water source on soil heavy metal contents.

\section{Soil and water sampling}

At the beginning of the experiment, soil samples were collected at $0-0.20 \mathrm{~m}$ and $0.20-0.40 \mathrm{~m}$ depth, to assess the initial main soil characteristics (Table 3). Afterwards soil samples were collected in each unit of the two experimental fields throughout the experimental period; details of sampling dates are reported in Table 2. Moreover, periodically, samples of water sources (FW, TW, SW) were taken to quantify the heavy metals content. Water samples were filtered on $0.45 \mu \mathrm{m}$ membrane, acidified with HNO3 3\% and then analysed by Inductively Coupled Plasma-Optical Emission spectrometry (ICP-OES) [31]. Heavy metals concentrations $(\mathrm{Cd}, \mathrm{Cr}, \mathrm{Cu}, \mathrm{Ni}, \mathrm{Pb}$ and $\mathrm{Zn}$ ) in the water sources investigated were lower than the limits of instrumental quantification $(\mathrm{LOQ}=10 \mathrm{ppb}$ ), except for $\mathrm{Cu}$ and $\mathrm{Zn}$ in one sampling time (respectively, $26.64 \mu \mathrm{g} \mathrm{L}^{-1}$ and $65.46 \mu \mathrm{L} \mathrm{L}^{-1}$ in SW).

All soil samples were air dried and ground to pass a 2-mm mesh sieve and then analysed. The heavy metal $(\mathrm{Cd}, \mathrm{Cr}, \mathrm{Cu}, \mathrm{Ni}$, $\mathrm{Pb}$ and $\mathrm{Zn}$ ) soil content was quantified by ICP-OES on extracts obtained after digestion in HNO3 65\% in a pressurized microwave [32]. Total nitrogen (N) was analyzed according to the Kjeldahl procedure and TOC content was quantified, on soil samples sieved at $0.5 \mathrm{~mm}$, by the dry-combustion procedure [33] with a TOC Vario Select analyser (Elementar, Germany).

\section{Statistical analysis}

\section{Preliminary statistical analysis for yield response}

Descriptive statistics were computed on heavy metal concentrations ( $\mathrm{Cr}, \mathrm{Cu}, \mathrm{Ni}, \mathrm{Pb}, \mathrm{Zn}$ ) for each experimental field in order to synthesize the main features of data distribution. In 
addition, the homogeneity of variance across sampling times (T), water source (WS) and soil depth (SD) was tested using Bartlett's test.

\section{Linear mixed effect model}

For any variable investigated, the ordinary least squares model (OLS) assumes that the normal random errors are independent and identically distributed (iid), or in symbol, e $\sim \mathrm{N}\left(0, \sigma^{2} \mathrm{I}\right)$ where I is identity matrix [34-36].

The OLS can be written using matrix notation as:

$$
Y=X \beta+e
$$

where $\mathrm{Y}$ is the vector of the responses, $\mathrm{X}$ the matrix of the observations, $\beta$ the vector of the unknown fixed effect coefficients and e the vector of independent and identically distributed (iid) normal random errors.

However, often the independence assumption about $\mathrm{Y}$ residuals is too restrictive because residuals may show correlations; linear mixed effect model extends the general linear model by allowing elements of Y to be correlated both on time and space. This can be performed through

(i) A specification of the covariance function of $\mathbf{e}$ as a function of the distance between two locations or observations $i$ and $j$ $\left(d_{i j}\right)$, with $\mathbf{e} \sim \mathrm{N}(0, \mathbf{R})$, for both spatial or temporal variability;

(ii) the addition of a random effect in the model $(\mathbf{Z u})$, with $\mathbf{u}$ $\sim \mathrm{N}(0, \mathbf{G})$, where $\mathbf{Z}$ is the matrix of the observations of the random effects and $\mathbf{u}$ the vector of the unknown random effect coefficients. $\mathbf{G}$ represents the covariance matrix of the random model effects, $\mathbf{u}$, and $\mathbf{R}$ the covariance matrix of the model error.

In the correlated error (spatial or temporal) model, the error variance of the OLS model $\left(\sigma^{2} \mathbf{I}\right)$ is split into a (spatially or temporally) structured variance $\left(\sigma_{P}^{2} \mathbf{F}\right)$, where $\mathrm{F}$ is an $\mathrm{N} \times \mathrm{N}$ matrix whose ijth element is $\mathrm{f}\left(\mathrm{d}_{\mathrm{ij}}\right)$, and an independent (residual) variance $\left(\sigma_{I}^{2} \mathbf{I}\right)$ [37].

In order to test the impact of irrigation with different water sources on soil metals concentrations, the following regression models were estimated and compared: ordinary least squares (OLS) models and linear mixed effects (LME) models with Results and Discussion temporal residual autocorrelation and heteroscedasticity [38].

The different temporal statistical models were fitted considering sampling time as a repeated factor and the temporal relationship was explored by testing the following variancecovariance structures for the residuals:

a) a compound symmetry structure (CS) model, which assumes a single variance $\left(\sigma^{2}\right)$ for all time points and a single covariance $\left(\sigma_{1}\right)$ for each of the pairs [23].

b) a homoscedastic autoregressive structure of order 1 (AR(1)), with correlations that vary with distance and decline exponentially with the time series [34]. The AR(1) covariance structure has two unknown parameters: the variance $\left(\sigma_{t}^{2}\right)$ and the lag-one correlation $(\rho t)$.

c) a first-order autoregressive structure with heterogeneous variances (ARH(1)); this structure allows variance to change over time (SAS online guide) with heterogeneity of variances caused by years/time points [40].

Sampling time was included in the model also as a fixed effect, in order to assess systematic or trend component in crop parameters variation $[23,34,35]$. Null models, including the same fixed effects of the repeated models but neglecting any correlation, were also computed. They were used as a control for the evaluation of the gain in model fit by the other approaches [27].

\section{Comparison of different models}

The different models tested were compared using likelihoodratio test (LRT) and information criteria based on likelihood estimations $[26,35,41]$. The LRT allows the comparison of the model's fit for nested models [23].

For comparisons of nested as well not nested models, the information criteria based on likelihood estimations can be used $[27,28,39]$ and the model with lower values for the information criteria is preferred [37].

All statistical analyses were computed using SAS/STAT (release 9.3, SAS INSTITUTE) and the models were estimated using PROC MIXED. The repeated statement controls the covariance structure imposed upon the residuals [42].

Table 3: Main average soil characteristics at the beginning of the experiment in the $0-0.40 \mathrm{~m}$ soil layer in two experimental fields and the thresholds defined by national law (D.Lgs. 152/2006).

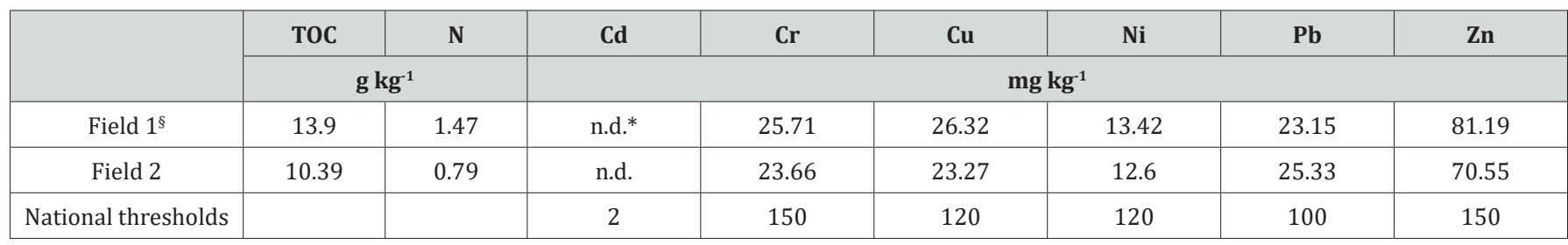

§Start date: January 2013 for field 1 and May 2013 for field 2.

${ }^{*}$ n.d. indicates that $\mathrm{Cd}$ concentrations were lower than the limits of instrumental quantification (LOQ $\left.=10 \mathrm{ppb}\right)$. 
In Table 3, the average contents of soil heavy metals at the beginning of the experiment were reported. Cadmium concentrations were lower than the limits of instrumental quantification (LOQ Limit of quantification $=10 \mathrm{ppb}$ ). No significant difference was observed for the other heavy metals ( $\mathrm{Cr}$, $\mathrm{Cu}, \mathrm{Ni}, \mathrm{Pb}$ and $\mathrm{Zn})$ between upper $(0-0.20 \mathrm{~m})$ and deeper $(0.20-$ $0.40 \mathrm{~m}$ ) soil layers. In any case, the soil concentrations were lower than the limits set by Italian law for soils in public, private and residential areas (D.Lgs. 152/2006).
Descriptive statistics for soil heavy metal concentrations computed on the whole set of observations $(n=54)$ for each experimental field are reported in Table $4 \& 5$. KolmogorovSmirnov test results were not significant except for $\mathrm{Cu}$ and $\mathrm{Zn}$ in field 1 and $\mathrm{Pb}$ in field 2. However, mainly for $\mathrm{Cu}$ and $\mathrm{Zn}$ in field 1, coefficients of skewness and kurtosis were close to zero, indicating no substantial departure from normal distribution; for this reason, normality was assumed, and the data were analyzed in the original scale.

Table 4: Descriptive statistics computed on the whole dataset of soil heavy metals concentrations for Field $1(n=54)$.

\begin{tabular}{|c|c|c|c|c|c|c|c|}
\hline Variable & Unit & Mean & Median & St dev & Skewness & Kurtosis & K-S (Pr>D) \\
\hline $\mathrm{Cr}$ & $\mathrm{mg} \mathrm{kg}^{-1}$ & 23.8544 & 24.6542 & 1.9426 & -0.7933 & -0.0272 & $<0.0100$ \\
\hline $\mathrm{Cu}$ & $\mathrm{mg} \mathrm{kg}^{-1}$ & 23.6135 & 23.2123 & 2.8248 & 1.3093 & 3.6859 & 0.0154 \\
\hline $\mathrm{Ni}$ & $\mathrm{mg} \mathrm{kg}^{-1}$ & 13.5951 & 13.6189 & 0.8859 & -0.1407 & -0.6418 & $>0.1500$ \\
\hline $\mathrm{Pb}$ & $\mathrm{mg} \mathrm{kg}^{-1}$ & 21.093 & 21.2932 & 2.1809 & -0.1372 & -0.3246 & $>0.1500$ \\
\hline $\mathrm{Zn}$ & $\mathrm{mg} \mathrm{kg}^{-1}$ & 70.6897 & 68.265 & 9.1774 & 0.6274 & 0.0815 & 0.021 \\
\hline
\end{tabular}

Table 5: Descriptive statistics computed on the whole dataset of soil heavy metals concentrations for Field 2.

\begin{tabular}{|c|c|c|c|c|c|c|c|}
\hline Variable & Unit & Mean & Median & St dev & Skewness & Kurtosis & K-S (Pr>D) \\
\hline $\mathrm{Cr}(54) \S$ & $\mathrm{mg} \mathrm{kg}^{-1}$ & 24.2572 & 24.3269 & 3.4173 & 0.3994 & 0.0299 & $>0.1500$ \\
\hline $\mathrm{Cu}(54)$ & $\mathrm{mg} \mathrm{kg}^{-1}$ & 24.8131 & 24.9947 & 2.8528 & 0.247 & 0.1942 & $>0.1500$ \\
\hline $\mathrm{Ni}(54)$ & $\mathrm{mg} \mathrm{kg}^{-1}$ & 13.4472 & 13.0867 & 1.4939 & 0.8947 & 0.9018 & 0.0731 \\
\hline $\mathrm{Pb}(54)$ & $\mathrm{mg} \mathrm{kg}^{-1}$ & 22.9534 & 21.2479 & 9.0321 & 3.6029 & 17.2066 & $<0.0100$ \\
\hline $\mathrm{Zn}(51)$ & $\mathrm{mg} \mathrm{kg}^{-1}$ & 70.6523 & 69.7036 & 9.2544 & 0.6932 & 0.0127 & $>0.1500$ \\
\hline
\end{tabular}

§In brackets, the number of observations is reported.

Table 6: Bartlett's homogeneity of variance test (P value) performed over water source (WS), sampling time (time) and soil depth (SD) in Field 1 and Field 2.

\begin{tabular}{|c|c|c|c|c|c|c|c|}
\hline \multirow{2}{*}{ Variable } & \multirow{2}{*}{ Unit } & \multicolumn{3}{|c|}{ Field 1 } & \multicolumn{3}{c|}{ Field 2 } \\
\cline { 3 - 8 } & & WS (3) & Time (3) & SD (2) & WS (3) & Time (3) & SD (2) \\
\hline $\mathrm{Cr}$ & $\mathrm{mg} \mathrm{kg}^{-1}$ & 0.0111 & 0.0122 & 0.5529 & 0.2754 & 0.2894 & 0.1821 \\
\hline $\mathrm{Cu}$ & $\mathrm{mg} \mathrm{kg}^{-1}$ & 0.0672 & 0.0358 & 0.2794 & 0.3785 & 0.2297 & 0.115 \\
\hline $\mathrm{Ni}$ & $\mathrm{mg} \mathrm{kg}^{-1}$ & 0.6126 & 0.0387 & 0.6388 & 0.1259 & 0.0264 & 0.03 \\
\hline $\mathrm{Pb}$ & $\mathrm{mg} \mathrm{kg}^{-1}$ & 0.2783 & 0.005 & 0.6487 & $<.0001$ & $<.0001$ & 0.0063 \\
\hline $\mathrm{Zn}$ & $\mathrm{mg} \mathrm{kg}^{-1}$ & 0.3705 & 0.6108 & 0.1821 & 0.0636 & 0.3466 & 0.5368 \\
\hline
\end{tabular}

$\S$ In brackets, the number of groups is reported.

Results of Bartlett's homogeneity of variance test indicated that variances were homogeneous over water source (except for $\mathrm{Cr}$ in field 1 and $\mathrm{Pb}$ in field 2) and soil depth (except for $\mathrm{Ni}$ and $\mathrm{Pb}$ in field 2) (Table 6). Heteroscedasticity was instead observed over sampling time for the majority of the variables especially in field 1 (Table 6).

Table 7: Significance of the likelihood-ratio test (LRT) for the evaluation of the different covariance models for the analysis performed on Field 1 and Field 2 datasets. Significant values are reported in bold characters.

\begin{tabular}{|c|c|c|c|c|c|c|c|c|c|}
\hline \multicolumn{3}{|c}{ Field 1 } & \multicolumn{3}{c|}{ Field 2 } \\
\hline & Null Model & CS & AR(1) & ARH(1) & & Null Model & CS & AR(1) & ARH(1) \\
\hline $\mathrm{Cr}$ & - & 0.0944 & $\mathbf{0 . 0 1 6 7}$ & $\mathbf{0 . 0 1 5 3}$ & $\mathrm{Cr}$ & - & 0.2562 & 0.9002 & 0.4429 \\
\hline $\mathrm{Cu}$ & - & 0.6715 & 0.8559 & $\mathbf{0 . 0 0 1 8}$ & $\mathrm{Cu}$ & - & $\mathbf{0 . 0 0 0 6}$ & $\mathbf{0 . 0 0 0 6}$ & $<\mathbf{0 . 0 0 0 1}$ \\
\hline $\mathrm{Ni}$ & - & 0.6606 & 0.1034 & $\mathbf{0 . 0 0 5 5}$ & $\mathrm{Ni}$ & - & 0.2185 & 0.84 & 0.224 \\
\hline $\mathrm{Pb}$ & - & 0.3115 & 0.0592 & $\mathbf{0 . 0 1 5}$ & $\mathrm{Pb}$ & - & 0.1707 & 0.1302 & $<\mathbf{0 . 0 0 0 1}$ \\
\hline $\mathrm{Zn}$ & - & 0.5133 & 0.8855 & 0.9916 & $\mathrm{Zn}$ & - & $\mathbf{0 . 0 0 4 9}$ & $\mathbf{0 . 0 1 6 6}$ & $\mathbf{0 . 0 0 0 1}$ \\
\hline
\end{tabular}


Significant temporal covariance structures were observed. In Table 7, the results of the comparison of the different covariance models tested, evaluated using likelihood-ratio test (LRT), are reported.

The compound symmetry (CS) structure models did not significantly differ from the null models except for $\mathrm{Cu}$ and $\mathrm{Zn}$ in field 2, as indicated by the significance of the likelihood-ratio test results $(\mathrm{P}=0.0006$ and $\mathrm{P}=0.0049$, respectively). Similar results were obtained for the autoregressive model of order 1 (AR(1)) which was significantly different from the null model for $\mathrm{Cu}$ $(\mathrm{P}=0.0006)$ and $\mathrm{Zn}(\mathrm{P}=0.0166)$ in field 2 and for $\mathrm{Cr}(\mathrm{P}=0.0167)$ in field 1; in addition, $\mathrm{Pb}$ showed a result close to the significant threshold ( $\mathrm{P}=0.0592)$.

Finally the autoregressive heteroscedastic models (ARH(1)), allowing a different variance per each sampling time, gave a significant better fitting than the homoscedastic and not correlated error models for all cases investigated, except for $\mathrm{Zn}$ in field 1 and $\mathrm{Cr}$ and $\mathrm{Ni}$ in field 2 (Table 7). The autoregressive heteroscedastic models, when significant, were then selected for fixed effects evaluation (Table $7 \&$ 8); in the other cases, null models were taken into account.

Table 8: Effect of sampling time (T), water source (WS) and soil depth (SD) on heavy metal concentrations in Field 1 and Field 2.

\begin{tabular}{|c|c|c|c|c|c|c|c|c|c|c|c|}
\hline \multirow{2}{*}{ Field 1} & $\mathrm{Cr}$ & $\mathbf{C u}$ & $\mathbf{N i}$ & $\mathbf{P b}$ & Zn & \multirow{2}{*}{ Field 2} & $\mathrm{Cr}$ & $\mathrm{Cu}$ & $\mathbf{N i}$ & $\mathbf{P b}$ & $\mathrm{Zn}$ \\
\hline & \multicolumn{5}{|c|}{$\mathrm{mg} \mathrm{kg}^{-1}$} & & \multicolumn{5}{|c|}{$\mathrm{mg} \mathrm{kg}^{-1}$} \\
\hline $\begin{array}{l}\text { Sampling } \\
\text { Time (T) }\end{array}$ & $<0.0001$ & 0.0312 & 0.0304 & 0.0025 & 0.0017 & $\begin{array}{l}\text { Sampling } \\
\text { time }(\mathrm{T})\end{array}$ & 0.3173 & 0.0003 & 0.0032 & 0.007 & 0.0389 \\
\hline 2013_Sept & $24.375 \mathrm{a}$ & $25.433 \mathrm{a}$ & $13.294 \mathrm{~b}$ & $21.025 \mathrm{~b}$ & $69.637 \mathrm{~b}$ & 2013_May & 23.66 & $23.274 \mathrm{~b}$ & $12.599 \mathrm{~b}$ & $25.333 \mathrm{a}$ & $70.553 \mathrm{ab}$ \\
\hline 2014_May & $24.805 \mathrm{a}$ & $22.257 \mathrm{~b}$ & $13.989 a$ & $22.480 \mathrm{a}$ & $65.888 \mathrm{~b}$ & 2013_Sept & 23.993 & $25.379 a$ & $13.837 \mathrm{a}$ & $20.416 \mathrm{~b}$ & $67.512 b$ \\
\hline 2014_Sept & $22.383 \mathrm{~b}$ & $23.150 \mathrm{ab}$ & $13.501 \mathrm{ab}$ & $19.773 \mathrm{~b}$ & $76.544 \mathrm{a}$ & 2014_June & 25.118 & $25.787 \mathrm{a}$ & $13.905 \mathrm{a}$ & $23.111 \mathrm{a}$ & $73.875 \mathrm{a}$ \\
\hline $\begin{array}{c}\text { Water } \\
\text { Source } \\
\text { (WS) }\end{array}$ & 0.2107 & 0.7092 & 0.1359 & 0.1255 & 0.4884 & $\begin{array}{c}\text { Water } \\
\text { Source } \\
\text { (WS) }\end{array}$ & 0.5984 & 0.4762 & 0.2674 & 0.0605 & 0.8147 \\
\hline FW & 23.681 & 23.733 & 13.362 & 20.717 & 70.174 & FW & 24.496 & 23.691 & 13.463 & 18.171 & 69.1 \\
\hline TW & 23.671 & 23.191 & 13.547 & 20.798 & 69.425 & TW & 24.604 & 25.441 & 13.763 & 23.673 & 71.377 \\
\hline SW & 24.211 & 23.915 & 13.875 & 21.763 & 72.471 & SW & 23.672 & 25.307 & 13.116 & 27.016 & 71.347 \\
\hline Depth (SD) & 0.6119 & 0.2815 & 0.7436 & 0.7618 & 0.8049 & Depth (SD) & 0.2641 & 0.974 & 0.1125 & 0.7028 & 0.9817 \\
\hline $0-0.20 \mathrm{~m}$ & 23.923 & 24.028 & 13.627 & 21.028 & 70.425 & $0-0.20 \mathrm{~m}$ & 23.784 & 24.792 & 13.183 & 22.431 & 70.204 \\
\hline $\begin{array}{c}0.20-0.40 \\
\mathrm{~m}\end{array}$ & 23.785 & 23.199 & 13.563 & 21.158 & 70.954 & $\begin{array}{c}0.20-0.40 \\
\mathrm{~m}\end{array}$ & 24.731 & 24.834 & 13.712 & 23.475 & 71.119 \\
\hline WS*SD & 0.5428 & 0.7331 & 0.7709 & 0.4653 & 0.9866 & WS*SD & 0.2519 & 0.8481 & 0.1267 & 0.8119 & 0.8531 \\
\hline $1 \mathrm{WS} * \mathrm{~T}$ & 0.0008 & 0.0072 & 0.0233 & 0.0504 & 0.0692 & WS*T & 0.0979 & 0.1129 & 0.0163 & 0.0134 & 0.0511 \\
\hline $\mathrm{SD}^{* \mathrm{~T}}$ & 0.7425 & 0.8923 & 0.8097 & 0.9419 & 0.5902 & $\mathrm{SD}^{* \mathrm{~T}}$ & 0.5646 & 0.298 & 0.294 & 0.6537 & 0.2175 \\
\hline WS*SD*T & 0.8541 & 0.9383 & 0.5829 & 0.5345 & 0.4967 & WS*SD*T & 0.9436 & 0.9029 & 0.7464 & 0.7197 & 0.4565 \\
\hline FW§ & 0.7968 & 0.0009 & 0.5844 & - & - & FW & - & - & 0.0092 & 0.0595 & - \\
\hline TW & $<0.0001$ & 0.1644 & 0.0052 & - & - & TW & - & - & 0.0097 & 0.1517 & - \\
\hline SW & 0.2272 & 0.2593 & 0.0375 & - & - & SW & - & - & 0.0403 & 0.0014 & - \\
\hline
\end{tabular}

\&In the following lines, the significant interactions Water Source $x$ Sampling Time $\left(W S^{*} T\right)$ are detailed.

This finding is in line with the results of Bartlett test that highlighted the heterogeneity of variance among sampling times (Table 6). In addition, these results underline the existence of a residual correlation structure over time and then the choice of a classical not correlated error model would have caused inefficient estimation of treatment significance [23,25].

Statistical analysis of fixed effects indicated that soil heavy metal concentrations varied significantly across sampling times (except for $\mathrm{Cr}$ in field 2) and as effect of different water source within each sampling time (significant interaction WS $\mathrm{x}$ T for $\mathrm{Cr}$, $\mathrm{Cu}$ and $\mathrm{Ni}$ in field 1 and $\mathrm{Ni}$ and $\mathrm{Pb}$ in field 2) (Table 8).

In particular, heavy metal concentration in field 1 ranged between 22.38 to $24.81 \mathrm{mg} \mathrm{kg}^{-1}$ for $\mathrm{Cr}, 22.26$ to $25.43 \mathrm{mg} \mathrm{kg}^{-1}$ for $\mathrm{Cu}, 13.29$ to $13.99 \mathrm{mg} \mathrm{kg}^{-1}$ for $\mathrm{Ni}, 19.77$ to $22.48 \mathrm{mg} \mathrm{kg}^{-1}$ for $\mathrm{Pb}$ and 65.89 to $76.54 \mathrm{mg} \mathrm{kg}^{-1}$ for $\mathrm{Zn}$ (Table 8). In field 2, only Cr content did not show any significant change while $\mathrm{Cu}, \mathrm{Ni}, \mathrm{Pb}$ and $\mathrm{Zn}$ varied significantly ranging from 23.27 to $25.79 \mathrm{mg} \mathrm{kg}^{-1}, 12.60$ to $13.91 \mathrm{mg}$ $\mathrm{kg}^{-1}, 20.42$ to $25.33 \mathrm{mg} \mathrm{kg}^{-1}$ and 67.51 to $73.88 \mathrm{mg} \mathrm{kg}^{-1}$, respectively. 
As concern WS $\mathrm{x}$ T interaction, in field 1, the TW treatment showed significant differences for $\mathrm{Cr}$ and $\mathrm{Ni}$ contents in the three sampling dates, but no increase over time was observed (Figure 1); in fact $\mathrm{Cr}$ and $\mathrm{Ni}$ concentrations ranged from 20.23 to $25.95 \mathrm{mg}$ $\mathrm{kg}^{-1}$ and 12.66 to $14.53 \mathrm{mg} \mathrm{kg}^{-1}$, respectively, and the lowest values were recorded at the end of the experiment. In the SW treatment significant differences were observed only for $\mathrm{Ni}$ content, with values ranging from 13.21 to $14.25 \mathrm{mg} \mathrm{kg}^{-1}$. In any case, the treated wastewater on average did not cause increases compared with freshwater.

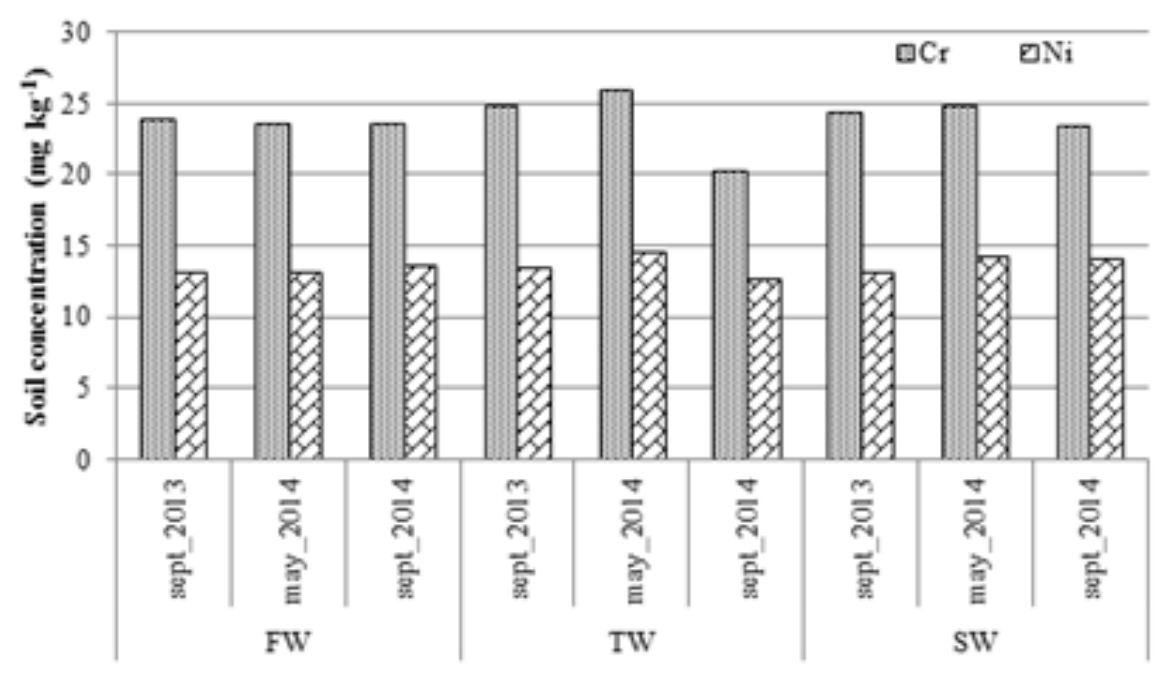

Figure 1: Soil Chromium ( $\mathrm{Cr}$ ) and Nichel (Ni) concentrations in three sampling dates under different water sources in field 1. FW, freshwater; TW, tertiary treated wastewater; SW, secondary treated wastewater.

In field 2, the WS $\mathrm{x}$ T interaction was significant for $\mathrm{Ni}$ and $\mathrm{Pb}$ contents (Table 8). In detail, Ni content varied significantly over time in all water source treatments (FW, TW and SW) with values ranging from 12.46 to $14.75 \mathrm{mg} \mathrm{kg}^{-1}$ and the highest concentrations observed in the FW treatment. Finally, in the SW treatment, $\mathrm{Pb}$ concentration ranged from 20.46 to $38.91 \mathrm{mg} \mathrm{kg}^{-1}$, and the highest values were recorded in the first sampling date.

At the end of experimental period (September 2014, Field 1; June 2014, Field 2) the soil heavy metal contents were close to those at the beginning of the experiment, before any wastewater application, except for $\mathrm{Ni}$ that showed slight increases.

Several researches showed that about 30 to $60 \%$ of the metals in the domestic sewage is associated with high-density particulate material and are consequently removed during the primary sedimentation stage $[43,44]$. In addition, during the secondary biological treatment stage, most of the metals are either sorbed onto extracellular polymer substances (EPS), assimilated in the microbial biomass, or form mineral precipitates. Therefore, the majority of heavy metals remains in the sludges and only a minor proportion is soluble, mostly as organic complexes [44-49], being a potential contamination source for soil and crops through irrigation.

Several short and medium term studies reported that the irrigation with treated urban wastewater did not affect soil content of heavy metals during growing season [50-54]. In greenhouse conditions, Garcia-Delgado et al. [53] studied the effects of fertigation with groundwater and treated municipal wastewater on soil properties and plant yield and quality. After one cropping season and a water supply of $910 \mathrm{~m} 3$ ha-1, none of the elements investigated ( $\mathrm{As}, \mathrm{Cr}, \mathrm{Cd}, \mathrm{Pb}, \mathrm{Ni}, \mathrm{Cu}$ and $\mathrm{Zn}$ ) showed significantly greater concentrations in the soil among irrigation treatments and in comparison with the beginning of the experiment. Also, in field conditions, Castro et al. [54] observed that, after three cropping seasons and about $6000 \mathrm{~m} 3$ ha- 1 of water supply, treated wastewater did not cause soil heavy metal accumulation. In a medium (less than 10 years of wastewater supply) and long (more than 10 years) term study, Ebrahim et al. [55] observed that the highest lead, chromium and nickel concentration was found in soils never irrigated, whereas the irrigation with treated wastewater did not induce any heavy metal accumulation. Therefore, the Authors hypothesised that the soils originally contained large amounts of these metals and irrigation leached the elements into deeper soil layers [55].

Long term studies reported significant increases of heavy metal concentrations in the upper soil layer, even if in many cases these concentrations resulted lower than the threshold values established by guidelines [15,56-60]. Accumulation of heavy metals, due to prolonged wastewater use, is strictly dependent on soil characteristics (texture and organic matter content, Xu et al. [59] and on wastewater composition or can be indirectly caused by a mismanagement of wastewater irrigation $[47,61]$. 
In our study, no significant difference was found between the two soil layers investigated. Friedel et al. [57] observed in a longterm experiment (80 years) significant increases of heavy metal contents $(\mathrm{Pb}, \mathrm{Cd}, \mathrm{Cu}, \mathrm{Zn})$ in the upper layer of the soil profile $(0$ $0.15 \mathrm{~m})$, although below EU thresholds, in correspondence of a greater organic matter content. Therefore, as reported by DuránÁlvarez \& Jiménez-Cisneros [19], organic matter enrichment in wastewater irrigated soils may result in greater retention of heavy metals by the solid matrix. Xu et al. [59] observed that, in a sandy soil with low organic matter content, the irrigation with reclaimed wastewater affected heavy metal levels and their distribution in soil profiles. In particular, heavy metals investigated $(\mathrm{Cr}, \mathrm{Cu}, \mathrm{Ni}$ and $\mathrm{Zn}$ ) reached the highest levels at $0.30-0.40 \mathrm{~m}$ horizons in plots irrigated for 8 years with effluent, whereas after 20 years, the highest concentrations occurred at deeper depths $(0.40-0.50 \mathrm{~m})$. These significant increases were found in long term (more than 8 years), notwithstanding the low heavy metal concentrations in the wastewater. In any case, the Authors highlighted that these increases should not represent a problem in soil accumulation or through food chain transfer, because in light soil texture and low OM content, heavy metals tend to be leached below the root zone..

With regard to the occurrence of heavy metals in agricultural soils irrigated with wastewater, Nicholson et al. [60] presented an inventory of sources (sludge, wastewater) of some heavy metals ( $\mathrm{Zn}, \mathrm{Cu}, \mathrm{Ni}, \mathrm{Pb}, \mathrm{Cr}$ and $\mathrm{Cd}$ ) in agricultural soils of England and Wales. The results showed that the greatest contribution to soil heavy metal accumulation came from the application of sludge from wastewater treatment plants, while irrigation appeared to be of little importance. According to this study, the time required for metal concentrations to reach maximum values permitted by international regulations is 80 years for zinc and at least 1256 years for cadmium [60]. In another study, Siebe \& Cifuentes [62] found that concentrations of heavy metals in long-term untreated-wastewater irrigated soils in central Mexico were 10 times lower than the limits set by the Danish regulations; moreover, the authors estimated that a century of irrigation is necessary to exceed these values.

As concerns the overall soil fertility, total organic carbon and nitrogen at the end of the experiment were close to the initial values, with average concentrations of 14.74 and $1.21 \mathrm{~g} \mathrm{~kg}^{-1}$ in field 1 and 10.56 and $0.88 \mathrm{~g} \mathrm{kg-1}$ in field 2, respectively. In particular, a slight increase of TOC was observed after secondary water application (SW) in both fields (15.58 and $11.87 \mathrm{~g} \mathrm{~kg}^{-1}$, respectively) and after tertiary treated water supply (TW) in field $1\left(15.46 \mathrm{~g} \mathrm{~kg}^{-1}\right)$. Other researches highlighted that the application of wastewater could maintain and increase soil organic carbon content [50,55,58]. In particular, Xu et al. [55] observed appreciable increases of organic matter (OM) with long term (8 - 20 years) reclaimed wastewater application. Abegunrin et al. [63], investigating the effect of irrigation with three wastewater sources (abattoir wastewater AW; bathroom and laundry wastewater - BW; cassava effluent - CE) on vegetable crops grown in buckets, observed a higher, although not significant, content of total organic carbon and nitrogen in the upper layer considered $(0-0.10 \mathrm{~m})$ after the application of BW and $\mathrm{AW}$ in comparison to the rainfed treatment.

Irrigation with treated municipal wastewater could therefore be of agricultural interest not only as an alternative water resource but also as nutrient and organic matter supply, with the known benefits on soil physical and overall quality. Moreover, the reuse of treated effluents for irrigation seems to be an environmentally safe disposal method; in fact, soil heavy metal concentrations, monitored in several studies, did not show harmful increase after continuous application. In any case, proper management for wastewater irrigation and continuous monitoring of water and soil quality are needed to avoid potential contaminations of soil and ground water, especially after long irrigation time.

\section{Conclusion}

Irrigation with treated municipal wastewater has become in several arid and semi-arid regions a common practice being an alternative water source that allows to fulfill actual irrigation needs and reduce the intensifying competition with higher-valued uses. Careful management of irrigation is however required to avoid contamination of soil and crops grown, in particular from heavy metals. When assessing the effects of wastewaters supply on soil and crops, repeated measurement experiments and rigorous methodological approaches are necessary to eliminate possible confounding effects due to residual correlations over time.

The results of this short-term research in a clay-loam soil, carried out comparing the effect of different water sources (freshwater, FW; tertiary treated wastewater, TW; secondary treated wastewater, SW) on soil heavy metal accumulation in two contiguous experimental fields belonging to a contemporaryphase crop rotation, highlighted that wastewater supply did not increase the heavy metals content $(\mathrm{Cr}, \mathrm{Ni}, \mathrm{Cu}, \mathrm{Pb}, \mathrm{Zn})$ in a soil layer of $0-0.40 \mathrm{~m}$ depth. Interactions between water source and sampling time were significant mainly under SW and TW supply ( $\mathrm{Cr}, \mathrm{Ni}, \mathrm{Cu}$ in field $1 ; \mathrm{Ni}$ and $\mathrm{Pb}$ in field 2). In any case no significant increase over time was recorded and the changes observed may be also attributed to soil spatial variability of heavy metal concentrations. Total organic carbon and nitrogen at the end of the experiment were close to the initial values, with a slight increase of TOC observed after secondary water application (SW) in both fields and after tertiary treated water supply (TW) in field 1. Among variance-covariance structures compared, ARH(1) models were significantly different from null models (OLS) in most of the cases investigated, confirming heterogeneity of variances observed over time, and were then used to analyze the effects of the factors under study. These results underline the existence of a significant residual correlation structure over time and then the choice of a classical not correlated error model would have caused inefficient estimation of treatment significance.

Treated municipal wastewater may represent a valuable resource, able to supply mineral nutrients to the plants and 
with unlikely risks of heavy metals contamination of soil and water bodies. However, appropriate soil selection, irrigation management and monitoring of wastewater composition and soil fertility are necessary, to take into account the presence of heavy metals and emerging pollutants as well.

\section{Acknowledgement}

The authors wish to thank the Italian Ministry of University and Research (MIUR) for its financial support under the Project In.T.e.R.R.A. (contract No. 01_01480) co-funded within the Italian Program "PON/Ricerca e Competitività 2007-2013". The authors want also to acknowledge Marcello Mastrangelo and Sabrina Moscelli for their help in chemical analysis.

\section{References}

1. Bixio D, C Thoeye, J De Koning, D Joksimovic, D Savic, et al. (2006) Wastewater reuse in Europe. Desalination 187(1-3): 89-101.

2. EU (2007) Addressing the challenge of water scarcity and droughts in the European Union. European Union (EU), Brussels (COM/2007/0414).

3. FAO (2012) Coping with water scarcity. An action framework for agriculture and food security. FAO Water Reports. Food and Agriculture Organization of the United Nations (FAO), Rome.

4. Moretti M, Van Passel S, Camposeo S, Pedrero F, Dogot T, et al. (2019) Modelling environmental impacts of treated municipal wastewater reuse for tree crops irrigation in the Mediterranean coastal region. Sci Total Environ 660: 1513-1521.

5. Amer KH (2010) Corn crop response under managing different irrigation and salinity levels. Agricultural Water Management 97(10): 1553-1563.

6. Campi P, Navarro A, Palumbo AD, Mastrangelo M, Lonigro A, et al. (2015) Bioenergy productivity of sugar beet irrigated with reclaimed wastewaters. Italian Journal of Agronomy 10(3): 155-159.

7. Vivaldi GA, Stellacci AM, Vitti C, Rubino P, Pedrero F, et al. (2017) Nutrient uptake and fruit quality in a nectarine orchard irrigated with treated municipal wastewater. Desalination and Water Treatment 71: 312-320.

8. Intriago JC, López-Gálvez F, Allende A, Vivaldi GA, Camposeo S, et al. (2018) Agricultural reuse of municipal waste water through an integral water reclamation management. J Environ Manag 213: 135-141.

9. Niemczynowicz J (1999) Urban hydrology and water management present and future challenges. Urban Water 1: 1-14.

10. WHO (2006) Guidelines for the safe use of wastewater, excreta and greywater - volume II, Wastewater use in agriculture, World Health Organization, Geneva, $\mathrm{CH}$.

11. Pedrero F, Camposeo S, Pace B, Cefola M, Vivaldi GA (2018) Use of reclaimed wastewater on fruit quality of nectarine in Southern Italy. Agricultural Water Management 203: 186-192.

12. Vivaldi GA, Camposeo S, Lopriore G, Romero-Trigueros C, Pedrero Salcedo F (2019) Using saline reclaimed water on almond grown in Mediterranean conditions: deficit irrigation strategies and salinity effects. Water Science and Technology: Water Supply 19(5): 14131421.

13. Toze $S$ (2006) Reuse of effluent water-benefits and risks. Agricultural Water Management 80(1-3): 147-159.
14. Becerra-Castro C, Lopes AR, Vaz-Moreira I, Silva EF, Manaia CM, et al. (2015) Wastewater reuse in irrigation: A microbiological perspective on implications in soil fertility and human and environmental health. Environment International 75: 117-135.

15. Siebe C, Fischer WR (1996)Adsorption of $\mathrm{Pb}, \mathrm{Cd}$, Cu and $\mathrm{Zn}$ by two soils of volcanic origin under long term irrigation with untreated sewage effluent in Central Mexico. Journal of Plant Nutrition and Soil Science 159: 357-364. In: WHO Guidelines, 2006.

16. Kiziloglu FM, Turan M, Sahin U, Kuslu Y, Dursun A (2008) Effects of untreated and treated wastewater irrigation on some chemical properties of cauliflower (Brassica Oleracea L. var. botrytis) and red cabbage (Brassica Oleracea L. var. rubra) grown on calcareous soil in Turkey. Agricultural Water Management 95(6): 716-724.

17. Wuana RA, Okieimen FE (2011) Heavy metals in contaminated soils: a review of sources, chemistry, risks and best available strategies for remediation. International Scholarly Research Network ISRN Ecology 2011(402647): 20.

18. Chibuike GU, Obiora SC (2014) Heavy metal polluted soils: effect on plants and bioremediation methods. Applied and Environmental Soil Science 2014(752708): 12 .

19. Durán Álvarez JC, Jiménez Cisneros B (2014) Beneficial and negative impacts on soil by the reuse of treated/untreated municipal wastewater for agricultural irrigation - A review of the current knowledge and future perspectives. In: Maria C Hernandez-Soriano (Ed.), Environmental Risk Assessment of Soil Contamination, Chapter 5, pp. 137-197.

20. Mühlbachová G, Simon T, Pechová M (2005) The availability of Cd, Pb and $\mathrm{Zn}$ and their relationships with soil $\mathrm{pH}$ and microbial biomass in soils amended by natural clinoptilolite. Plant, Soil and Environment 51: 26-33.

21. Wang AS, Angle JS, Chaney RL, Delorme TA, Reeves RD (2006) Soil pH effects on uptake of $\mathrm{Cd}$ and $\mathrm{Zn}$ by Thlaspi caerulescens. Plant and Soil 281(1-2): 325-337.

22. Zhao K, Liu X, Xu J, Selim HM (2010) Heavy metal contaminations in a soil-rice system: identification of spatial dependence in relation to soil properties of paddy fields. J Hazard Mater 181(1-3): 778-787.

23. Campi P, Mastrorilli M, Stellacci AM, Modugno F, Palumbo AD (2019) Increasing the effective use of water in green asparagus through deficit irrigation strategies. Agricultural Water Management 217: 119-130.

24. Piepho HP, Büchse A, Richter C (2004) A mixed modelling approach for randomized experiments with repeated measures. Journal of Agronomy and Crop Science 190(4): 230-247.

25. Hong N, White JG, Gumpertz ML, Weisz R (2005) Spatial analysis of precision agriculture treatments in randomized complete blocks: guidelines for covariance model selection. Agronomy Journal 97: 1082-1096.

26. Hu X, Spilke J (2009) Comparison of various spatial models for the analysis of hybrid trials. New Zealand Journal of Agricultural Research 52: 277-287.

27. Ritcher C, Kroschewski B (2006) Analysis of a long-term experiment with repeated measurement models. Journal of Agronomy and Crop Science 192(1): 55-71.

28. Verbeke G, Molenberghs G (2000) Linear mixed models for longitudinal data. Springer, New York.

29. Campi P, Palumbo AD, Mastrorilli M (2009) Effects of tree windbreak on microclimate and wheat productivity in a Mediterranean environment. European Journal of Agronomy 30(3): 220-227. 
30. Vivaldi GA, Camposeo S, Rubino P, Lonigro A (2013) Microbial impact of different types of municipal wastewaters used to irrigate nectarines in Southern Italy. Agriculture, Ecosystems \& Environment 181: 50-57.

31. APAT, IRSA-CNR (2003) Metodi analitici per le acque. 3020. Determinazione di elementi chimici mediante spettrometria di emissione con sorgente al plasma (ICP-OES). Vol. I., p. 490.

32. ANPA Manuali e linee guida 3/2001 (2001) [ANPA Handbooks and Guidelines 3/2001] Metodi di analisi del compost [Methods of compost analysis].

33. Vitti C, Stellacci AM, Leogrande R, Mastrangelo M, Cazzato E, et al (2016) Assessment of organic carbon in soils: A comparison between the Springer-Klee wet digestion and the dry combustion methods in Mediterranean soils (Southern Italy). Catena 137: 113-119.

34. Rodrigues MS, Corà JE, Castrignanò A, Mueller TG, Rienzi E (2013) A spatial and temporal prediction model of corn grain yield as a function of soil attributes. Agronomy Journal 105(6): 1878-1886.

35. Ventrella D, Stellacci AM, Castrignanò A, Charfeddine M, Castellini M (2016) Effects of crop residue management on winter durum wheat productivity in a long term experiment in Southern Italy. European Journal of Agronomy 77: 188-198.

36. Barca E, De Benedetto D, Stellacci AM (2019) Contribution of EMI and GPR proximal sensing data in soil water content assessment by using linear mixed effects models and geostatistical approaches. Geoderma 343: $280-293$

37. Littell RC, Milliken GA, Stroup W, Wolfinger RD, Schabenberger 0 (2006) SAS system for mixed models. SAS Inst, Cary, NC.

38. Schabenberger O, Gotway CA (2005) Statistical methods for spatial data analysis. CRC Press, Boca Raton, FL, p. 760.

39. Onofri A, Seddaiu G, Piepho HP (2016) Long-term experiments with cropping systems: case studies on data analysis. European Journal of Agronomy 77: 223-235.

40. Castrignanò A, Buttafuoco G, Pisante M, Vonella V (2005) How spatial and temporal variability can affect fertilization trial results. In: Stafford JV (Ed.), Precision Agriculture, pp, 761-768.

41. Schabenberger O, Pierce FJ (2002) Contemporary statistical models for the plant and soil sciences. CRC Press, Boca Raton, FL, p. 512.

42. Moser EB (2004) Repeated measures modelling with PROC MIXED. Paper 188-29, Statistics and data analysis. Proceedings of the TwentyNinth Annual SAS ${ }^{\circledR}$ Users Group International Conference; Cary, NC: SAS Institute Inc.

43. Nielsen JS, Hrudey SE (1983) Metal loadings and removal at a municipal activated sludge plant. Water Research 17: 1041-1052.

44. Sterritt RM, Lester JN (1984) Mechanisms of heavy metal concentration into sewage sludge. In: Processing and use of sewage sludge. In: P L. L'Hermiteand H. Ott (Ed.), Reidel Pub. Co., Dordrecht, Holland, pp. 172175 .

45. Brown MJ, Lester JN (1979) Metal removal in activated sludge: The role of bacterial extracellular polymers. Water Research 13(9): 817-837.

46. Lun XZ, Christensen TH (1989) Cadmium complexation by solid waste leachates. Water Research 23(1): 81-84.

47. McNicol RD, Beckett PHT (1989) The distribution of heavy metals between the principal components of digested sewage sludge. Water Research 23(2): 199-206.

48. Guibaud G, Tixier N, Bouju A, Baudu M (2003) Relation between extracellular polymers' composition and its ability to complex $\mathrm{Cd}, \mathrm{Cu}$ and $\mathrm{Pb}$. Chemosphere 52(10): 1701-1710.
49. Comte S, Guibaud G, Baudu M (2008) Biosorption properties of extracellular polymeric substances (EPS) towards $\mathrm{Cd}, \mathrm{Cu}$ and $\mathrm{Pb}$ for different $\mathrm{pH}$ values. Journal of Hazardous Materials 151(1): 185-193.

50. Feizi M (2001) Effect of treated wastewater on accumulation of heavy metals in plants and soils. International Workshop on Wastewater Reuse management, Seoul, Korea

51. Rusan MJM, Hinnawi S, Rousan L (2007) Long term effect of wastewater irrigation of forage crops on soil and plant quality parameters. Desalination 215(1-3): 143-152.

52. Dikinya 0, Areola O (2009) Comparative assessment of heavy metal concentration in treated wastewater irrigated soils cultivated to different crops in the Glen Valley, Botswana. African Crop Science Conference Proceedings, pp. 351-355.

53. García-Delgado C, Eymar E, Contreras JI, Segura ML (2012) Effects of fertigation with purified urban wastewater on soil and pepper plant (Capsicum annuum L.) production, fruit quality and pollutant contents. Spanish Journal of Agricultural Research 10(1): 209-221.

54. Castro E, Mañas P, De Las Heras J (2013) Effects of wastewater irrigation in soil properties and horticultural crop (lactuca sativa l.). Journal of Plant Nutrition 36(11): 1659-1677.

55. Ebrahim JE, Salih AA, Abahussain A (2016) Effect of long-term irrigation using treated wastewater on heavy metal contents of soils grown to Medicago sativa in the Kingdom of Bahrain. International Journal of Advance Agricultural Research 4: 20-29.

56. Siebe C (1995) Heavy metal availability to plants in soils irrigated with wastewater from Mexico City. Water Science \& Technology 32(12): 2934.

57. Friedel JK, Langer T, Siebe C, Stahr K (2000) Effects of long-term waste water irrigation on soil organic matter, soil microbial biomass and its activities in Central Mexico. Biological and Fertility of Soils 31(5): 414421.

58. Simmons RW, Pongsakul P (2002) Toward the development of an effective sampling protocol to "rapidly" evaluate the distribution of $\mathrm{Cd}$ in contaminated, irrigated rice based agricultural systems. Transactions of the $17^{\text {th }}$ world congress of soil science, Bangkok, 1421 August 2002. Vienna, International Union of Soil Science. In: WHO Guidelines, 2006

59. Xu J, Wu L, Chang AC, Zhang Y (2010) Impact of long-term reclaimed wastewater irrigation on agricultural soils: A preliminary assessment. Journal of Hazardous Materials 183(1-3): 780-786.

60. Nicholson FA, Smith SR, Alloway BJ, Carlton-Smith C, Chambers B] (2003) An inventory of heavy metals inputs to agricultural soils in England and Wales. Science of the Total Environment 311(1-3): 205219.

61. Bedbabis S, Trigui D, Ben Ahmed C, Clodoveo ML, Camposeo S, et al. (2015) Long-terms effects of irrigation with treated municipal wastewater on soil, yield and olive oil quality. Agric Water Manag 160: 14-21.

62. Siebe C, Cifuentes E (1995) Environmental Impact of Wastewater Irrigation in Central Mexico: An Overview. Int J Environ Health Res 5(2): 161-173.

63. Abegunrin TP, Awe GO, Idowua DO, Adejumobi MA (2016) Impact of wastewater irrigation on soil physico-chemical properties, growth and water use pattern of two indigenous vegetables in southwest Nigeria. Catena 139: 167-178. 

(CC) This work is licensed under Creative

DOI: 10.19080/IJESNR.2019.21.556100

\section{Your next submission with Juniper Publishers will reach you the below assets}

- Quality Editorial service

- Swift Peer Review

- Reprints availability

- E-prints Service

- Manuscript Podcast for convenient understanding

- Global attainment for your research

- Manuscript accessibility in different formats ( Pdf, E-pub, Full Text, Audio)

- Unceasing customer service

Track the below URL for one-step submission https://juniperpublishers.com/online-submission.php 